\title{
Effects of cycle peak temperature ratio on the performance of combined cycle power plant
}

\author{
Thamir K. Ibrahim ${ }^{1,2}$ and M. M. Rahman ${ }^{1,3}$ \\ ${ }^{1}$ Faculty of Mechanical Engineering, Universiti Malaysia Pahang \\ 26600 Pekan, Pahang, Malaysia. \\ Email: thamir@ump.edu.my \\ ${ }^{2}$ Mechanical Engineering Departments, College of Engineering \\ University of Tikrit, Tikrit, Iraq \\ ${ }^{3}$ Automotive Engineering Centre, Universiti Malaysia Pahang \\ 26600 Pekan, Pahang, Malaysia.
}

\begin{abstract}
Combined cycle power plant (CCPP) is currently the most promising technology to generate power at higher plant thermal efficiencies. The effects of the cycle peak temperature ratio on the improvement of the performance of the combined cycle power plant had been proposed. The MATLAB code was developed to utilize the performance of the CCPP. The results of this study showed that the overall thermal efficiency increased with the increase of cycle peak temperature ratio and decreased with the increase of air fuel ratio. Also, the increase of the cycle peak temperature ratio as well as the increase of the isentropic compressor efficiency led to the increase of the total power output. The thermal efficiencies for CCPP were higher compared to the gas turbine power plant.
\end{abstract}

Keywords: Combined cycle, cycle peak temperature ratio, thermal efficiency, power.

\section{INTRODUCTION}

The worldwide increase in energy demand has to be met in an environmentally friendly way and be efficient in use. Combined cycle power plant (CCPP) power generation is currently the most promising technology to generate power at higher plant thermal efficiencies. CCPP plants couple a Brayton cycle (topping cycle) with a Rankine cycle (the bottoming cycle)[1,2]. The hot exhaust gases from the gas turbine (Brayton cycle) deliver energy to produce high-pressure steam for the Rankine cycle. The heat recovery steam generator (HRSG) is the equipment, which is used to production steam. High efficiency in $\mathrm{CC}$ (up to 58\%) can be achieved for two main reasons [3-5] such as improvements in the gas turbine technology (i.e. higher cycle peak temperature ratio) and improvement in the HRSG design. In the power generation unit, the CCPP power plants are an attractive development. Under this, the attributed thermal efficiency of the CCPP is higher in comparison to the individual thermal efficiency of steam power plant or GT plant. As a result, due to the escalating fuel prices, the optimum design of the CCPP holds significant importance [1, 6-8]. For achieving optimum ST output, the appropriate usage of the GT exhaust heat in the ST cycle stands as the main challenge in a CCPP design. The power output of such cycles has increased according to the benefits of CCPP [9]. In contrast to the GT and ST plant, a higher overall thermal efficiency and power output 
have been identified for the CCPP plants [10]. In comparison to Ranking (ST) or Brayton (GT) cycles, the higher overall thermal efficiencies of a CCPP make them outstanding as a power generation unit. Thus, CCPP has been utilized on a comprehensive scale worldwide based on these lower emissions and advantages [11-18]. As a highly developed technology, the CCPP power plant produces electrical power at high efficiencies. The turbine inlet temperature of a GT cycle (topping cycle) has a higher temperature than the CCPP. In a heat recovery steam generator (HRSGs), the high temperature steam for the steam turbine is generated by using the temperature of the exhaust gases [19]. In comparison with the ST cycle (850K), the GT cycle can work at a higher temperature of $(1100 \mathrm{k}$ to $1800 \mathrm{~K})[20,21]$. By increasing the maximum temperature (turbine inlet temperature) of heat addition in the thermal cycle, working with low temperature of heat rejection or both, the thermal efficiency of any power plant cycle as a thermodynamic performance can be enhanced [22-24]. In the CCPP, the GT cycle works at a higher turbine inlet temperature and is linked with an ST cycle that operates at a lower temperature scale $[14,25,26]$. Moreover, in contrast to the GT power plant that works on its own, the heat rejection temperature (exhaust temperature) of the GT working in CCPP is lower. Thus, when compared with the levels of the GT cycle thermal efficiency and ST cycle thermal efficiency operating individually, the total effect is higher thermal efficiency of CCPP [27-29]. A parametric thermodynamic analysis of the CCPP cycle was presented in this work. The effects of the operating parameters, including the GT cycle peak temperature ratio, pressure ratio, isentropic compressor, efficiency and air-fuel ratio on the overall plant performance were investigated.

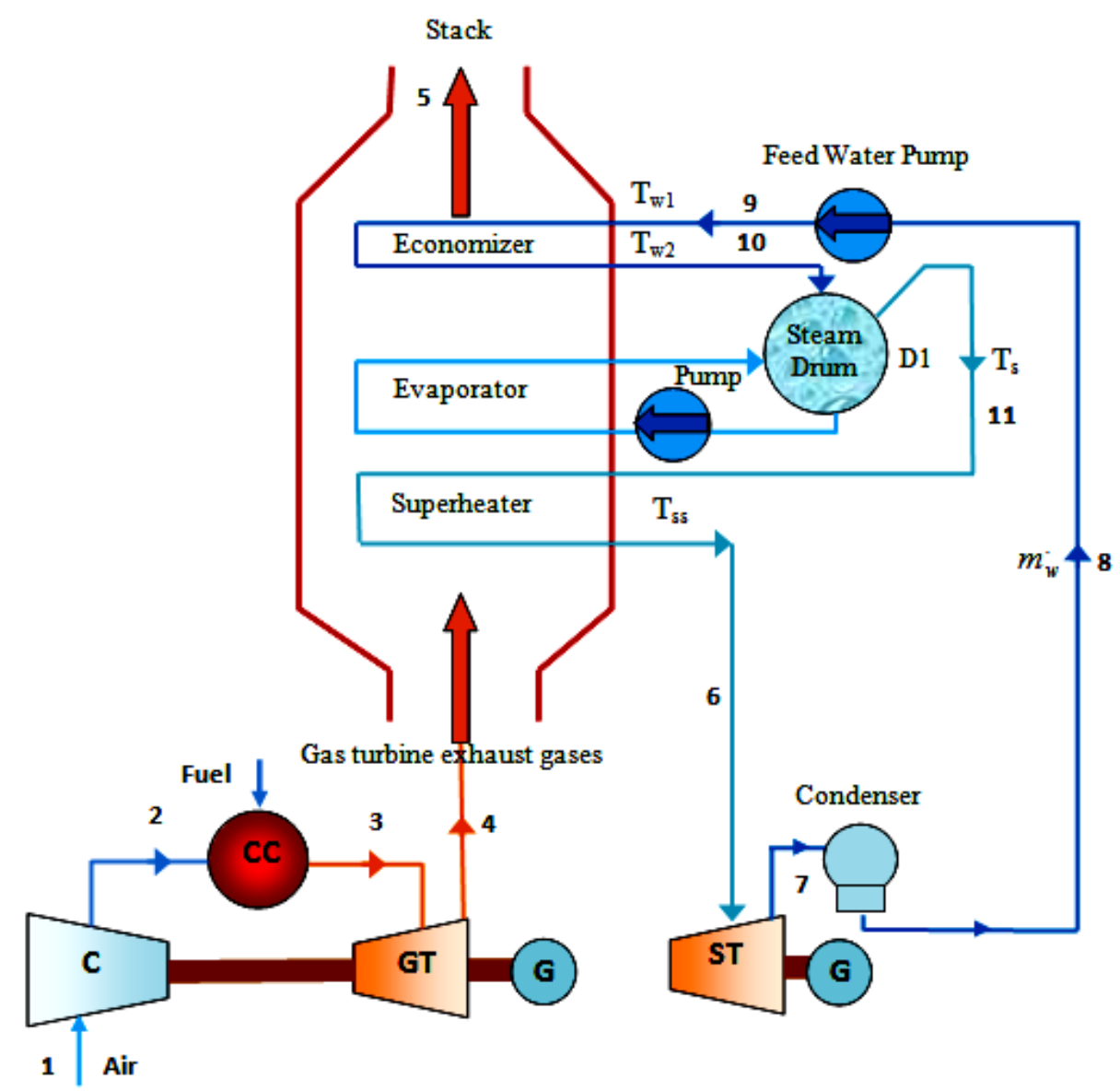

Figure 1. The schematic of a single-pressure combined cycle power plant. 


\section{Modeling OF COMbined CyCLE POWER PLANT}

A schematic of the CCPP and bottoming cycle using a single-pressure heat recovery steam generator (HRSG) without reheating is illustrated in Figure 1. To enable burning of natural gas for expansion in the GT, a combustor and a single stage axial flow compressor are included in the GT (topping cycle). For combining with fuel in order to produce high temperature flue gas, the principle of GT states that the air is compressed by the air compressor before being transferred to the combustion chamber (CC). Next, the GT which is linked to the generator's shaft for producing electricity becomes the recipient of the temperature flue gas [30]. As a gas turbine analysis, it is assumed that the compressor efficiency and the turbine efficiency are represented by $\eta_{c}$ and $\eta_{t}$ respectively.

The net work of the gas-turbine ( $\left.W_{\text {Gnet }}\right)$ was calculated by Eq. (1) $[12,15,25]$ :

$$
W_{\text {Gnet }}=C_{p g} \times T I T \times \eta_{t}\left(1-\frac{1}{r_{p}^{\frac{\gamma_{g}-1}{\gamma_{g}}}}\right)-C_{p a} \times T_{1}\left(\frac{r_{p}^{\frac{\gamma_{a}-1}{\gamma_{a}}}}{\eta_{m} \eta_{c}}\right)
$$

where $T_{3}=T I T$ is the turbine inlet temperature, $\mathrm{rp}$ is the compression ratio, $\gamma_{a}=1.4$, $\gamma_{g}=1.33, C_{p a}$ is the specific heat of air and $\eta_{m}$ is the mechanical efficiency of the compressor and turbine $[29,31,32]$ :

$$
C_{p a}=1.0189 \times 10^{3}-0.13784 T_{a}+1.9843 \times 10^{-4} T_{a}^{2}+4.2399 \times 10^{-7} T_{a}^{3}-3.7632 \times 10^{-10} T_{a}^{4}
$$

where $T_{a}=\frac{T_{2}-T_{1}}{2}$ in Kelvin.

The specific heat of flue gas $\left(C_{p g}\right)$ was given by Thamir and Rahman, [27]:

$$
C_{p g}=1.8083-2.3127 \times 10^{-3} T+4.045 \times 10^{-6} T^{2}-1.7363 \times 10^{-9} T^{3}
$$

The output power from the turbine $(\mathrm{P})$ was expressed as Eq. (4):

$$
P=\dot{m}_{g} \times W_{\text {Gnet }}
$$

where $\dot{m}_{g}$ is the mass flow rate of the exhaust gases through the gas-turbine, and expressed as Eq. (5):

$$
\dot{m}_{g}=\dot{m}_{a}+\dot{m}_{f}
$$

The specific fuel consumption (SFC) was determined by Eq. (6):

$$
S F C=\frac{3600 f}{W_{n e t}}
$$

The heat supplied was also expressed as Eq. (7) $[33,34]$ :

$$
Q_{\text {add }}=C_{p g} \times\left[T I T-T_{1} \times\left(1+\frac{r_{p}^{\frac{\gamma_{a}-1}{\gamma_{a}}}-1}{\eta_{c}}\right)\right]
$$

The gas-turbine efficiency $\left(\eta_{t h}\right)$ can be determined by Eq. (8) $[28,35]$ :

$$
\eta_{t h}=\frac{W_{\text {Gnet }}}{Q_{\text {add }}}
$$


When flowing into the HRSG, a decrease became imminent in the effluent exhaust gas temperature. The superheater, economizer and evaporator existed in the HRSG. Electricity was produced with the transmission of steam by the HRSG to the ST. The effluent condensate flowed from the ST into a condenser. Over here, waste heat was transferred by the cooling water to the cooling tower [36, 37]. In the last stage, the output from the condenser, namely the feed water, was suctioned by the feed water pump before transference to the HRSG [13, 38, 39]. This section explains the SPCC power plant whereas section 3.2 has already explained the model of the gas turbine. The assumption that $\eta_{s t}$ and $\eta_{p}$ represented steam turbine and pump efficiencies respectively is taken here. The solid and dashed lines represent the ideal and actual processes on the temperature entropy diagram illustrated by Figure 2 [40, 41].

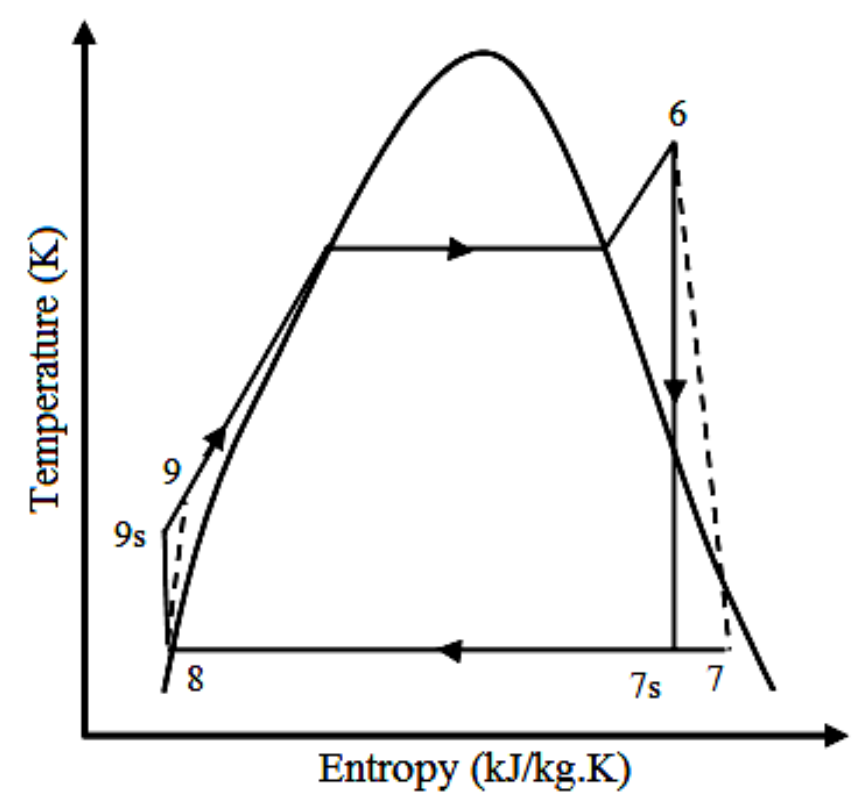

Figure 2. Temperature-entropy diagram for steam turbine plant.

For the CCGT plant, a single pressure HRSG is classified as a common type. The temperature profile for a single pressure HRSG case containing a superheater, economizer and evaporator is shown in Figure 3. Feed water temperature and blow down are the terminologies used for superheated steam temperature and pressure. Conditions of GT exhaust like temperature exhaust gases, flow rate and compositions are known as well. In the design mode, the aim was also to obtain the steam flow, gas and steam temperature profile. For calculating the HRSG temperature profile, the main parameters were the pinch point $\left(T_{p p}\right)$ and approach points $\left(T_{a p}\right)$. Figure 3 defines them which include the steam flow fall, the complete gas and steam temperature profiles [21, 30]. The values for $\left(T_{g 3}\right)$ and $\left(T_{w 2}\right)$ can be calculated while assumptions were made for the pinch and approach. Hence, as shown in Figure 2, the gas and water properties can be calculated by applying the energy balance for gas and water in every part. The following equations had been solved for obtaining the results:

Equation (9) expressed the superheater duty:

$$
Q_{s h}=m_{s}\left(h_{s h}-h_{s}\right)=m_{g} \times C_{p g} \times\left(T_{g 1}-T_{g 2}\right) \times h_{1 f}
$$




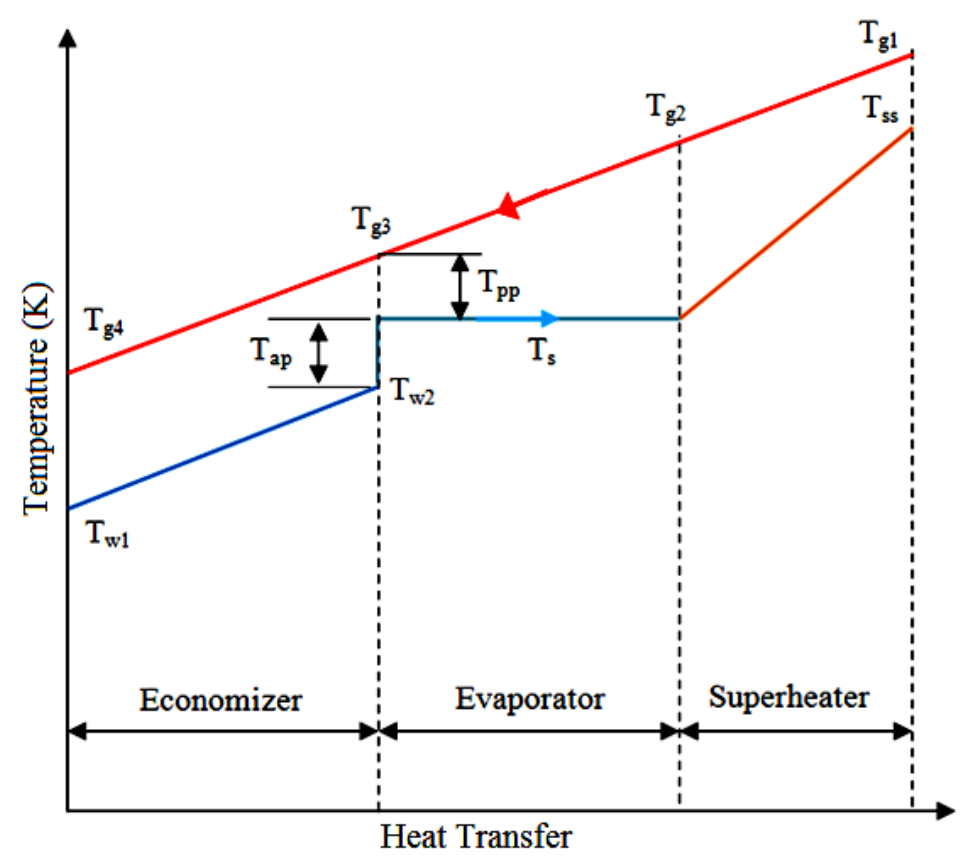

Figure 3. A typical temperature heat transfer diagram for single-pressure HRSG combined cycle

The heat loss factor is denoted by $h_{1 f}$, commonly lying in the range of 0.98 to $0.99[30,36,42]$.

The approach points $\left(T_{a p}\right)$ and the designed pinch point $\left(T_{p p}\right)$ were the basis for the thermal analysis of the HRSG. Equation (10) expressed the temperature of the gas being emitted from the evaporator:

$$
T_{g 3}=T_{s}+T_{p p}
$$

At superheated pressure, the saturation steam temperature is denoted by $T_{s}$. Moreover, equation (11) defined the temperature of the water entering the evaporator.

$$
T_{w 2}=T_{s}-T_{a p}
$$
$[43,44]$.

Equation (12) was used for calculating the mass flow rate of the generation steam

$$
m_{s}=\frac{m_{g}\left(C_{p g 1} T_{g 1}-C_{p g 3} T_{g 3}\right) \times h_{1 f}}{\left(h_{s s}-h_{w 2}\right)}
$$

As defined in equation (13), the energy balance was used for calculating the temperature of the gases that left the superheater:

$$
T_{g 2}=\frac{C_{p g 1} T_{g 1}}{C_{p g 2}}-\frac{m_{s}\left(h_{s s}-h_{s}\right)}{m_{g} C_{p g 2} \times h_{1 f}}
$$

The trial and error method on equation (13) was performed for calculating the specific heat $\left(C_{p g 2}\right)$ and $T_{\mathrm{g} 2}$. As shown in Figure 2, the energy balance of the economizer could be considered for calculating the temperature of the exhaust hot gases emitting the HRSG.

Equation (14) was another way of demonstrating the heat available from the exhaust gases:

$$
Q_{a v}=m_{g} \times C_{p g} \times\left(T_{g 1}-T_{g 4}\right) \times h_{1 f}
$$


where the exhaust temperature of the HRSG is represented by $T_{g 4}$.

The energy balance between states 4 and 5 can be considered for calculating the temperature of the hot gases leaving the HRSG [21]. This is shown in Figure 1.

$$
T_{g 4}=\frac{C_{p g 3} T_{g 3}}{C_{p g 4}}-\frac{m_{s}\left(h_{w 2}-h_{w 1}\right)}{m_{g} C_{p g 4} \times h_{1 f}}
$$

The ST became the recipient of the high pressure and high temperature steam obtained from the HRSG [45, 46]. Figure 2 shows the energy balance.

$$
W_{s t}=m_{s}\left(h_{6}-h_{7}\right)
$$

Equation (17) expressed the heat rejected from the condenser:

$$
Q_{\text {cond }}=m_{w}\left(h_{7}-h_{8}\right)
$$

The pump extracted the condensate from the condenser which was then elevated to the economizer pressure. Equation (18) presented the corresponding work:

$$
W_{p}=m_{w} \times v_{f 9}\left(p_{s h}-p_{c}\right)
$$

Hence, the ST power plant's net work is:

$$
W_{\text {snet }}=W_{s t}-W_{p}
$$

The ST power plant's efficiency is:

$$
\eta_{s t c}=\frac{W_{\text {snet }}}{Q_{a v}}
$$

Equation (21) represented the overall thermal efficiency of the CCGT power plant [15]:

$$
\eta_{\text {all }}=\frac{W_{\text {Gnet }}+W_{\text {snet }}}{Q_{\text {add }}}
$$

The heat rate of the CCPP is [32];

$$
H R_{t}=\frac{3600}{\eta_{\text {all }}}
$$

\section{RESULTS AND DISCUSSION}

The influences of different parameters in terms of the cycle peak temperature ratio, airfuel ratio, pressure ratio, and isentropic efficiency of the compressor and turbine, on the CCPP performance are presented in this section. The effects of these parameters on the power output and efficiency were obtained by the energy-balance utilizing the MATLAB software. Figure 4 shows the variation of cycle peak temperature ratio and air fuel ratio on the overall thermal efficiency. It can be seen that the overall thermal efficiency increased with the increase of cycle peak temperature ratio and decreased with the increase of air-fuel ratio (AFR). The overall thermal efficiency was increasing from 53\% to $56 \%$ when the AFR decreased from 52 to 36.

Figure 5 presents a relation between the cycle peak temperature ratios for different values of pressure ratio versus the overall thermal efficiency and total power outputs of the CCPP at constant turbine inlet temperature (TIT). In Figure 5(a), it can be seen that the total power output increases with the cycle peak temperature ratio at the lower pressure ratio. These unexpected results occured due to the calculation that was built with constant turbine inlet temperature and this led to the increase of the work of the compressor and stalled the work of the turbine constant, which was yielded to decrease the net work done in the GT cycle. In Figure 5(b), the thermal efficiency increases with the increase of the cycle peak temperature ratio as well as higher pressure ratio. However, 
the variation of overall thermal efficiency was insignificant at the lower pressure ratio and lower cycle peak temperature ratio.

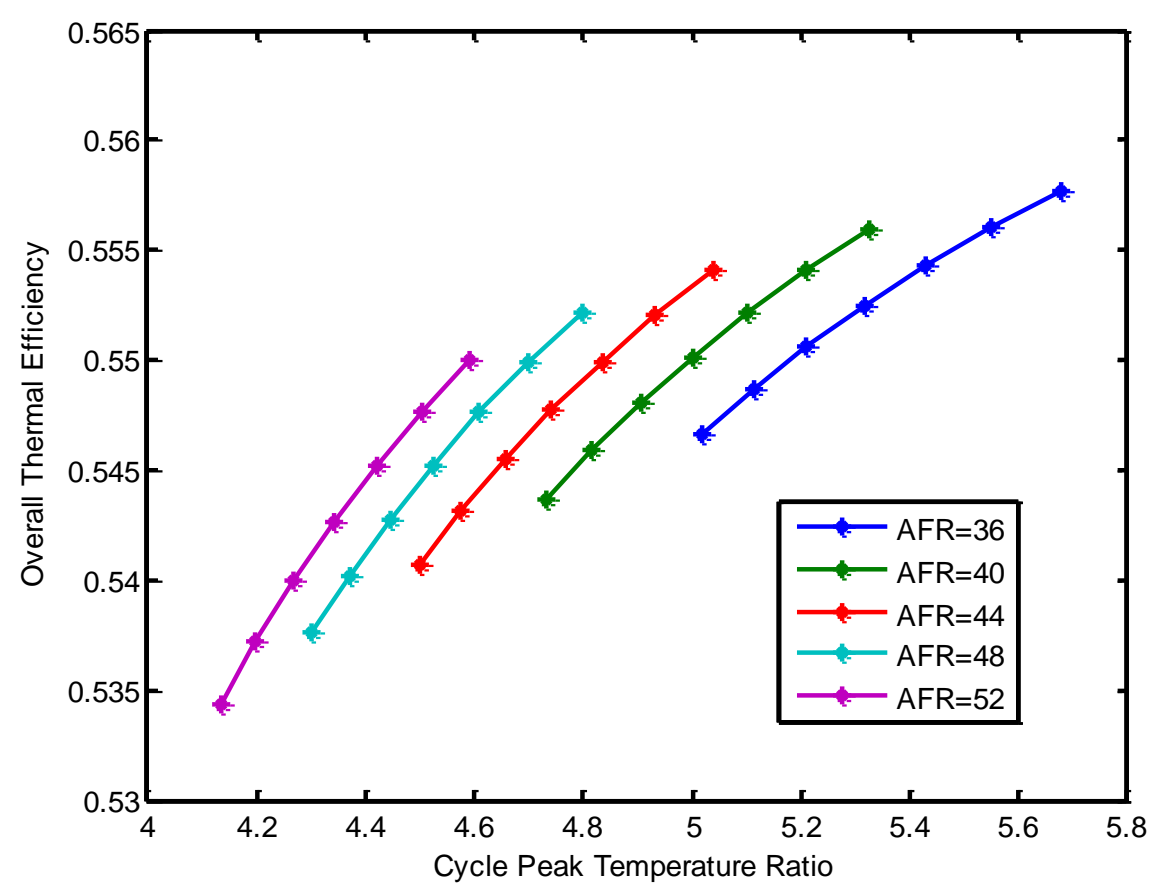

Figure 4. Variation of cycle peak temperature ratio and air fuel ratio on the overall thermal efficiency.

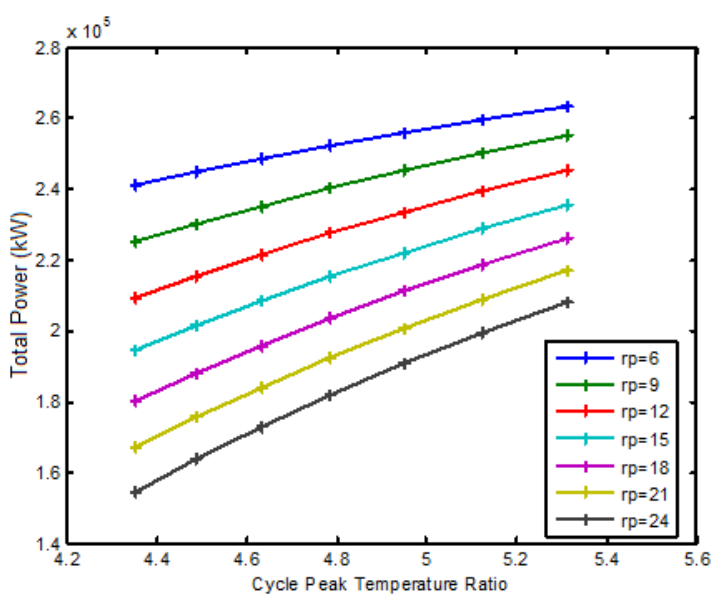

(a)

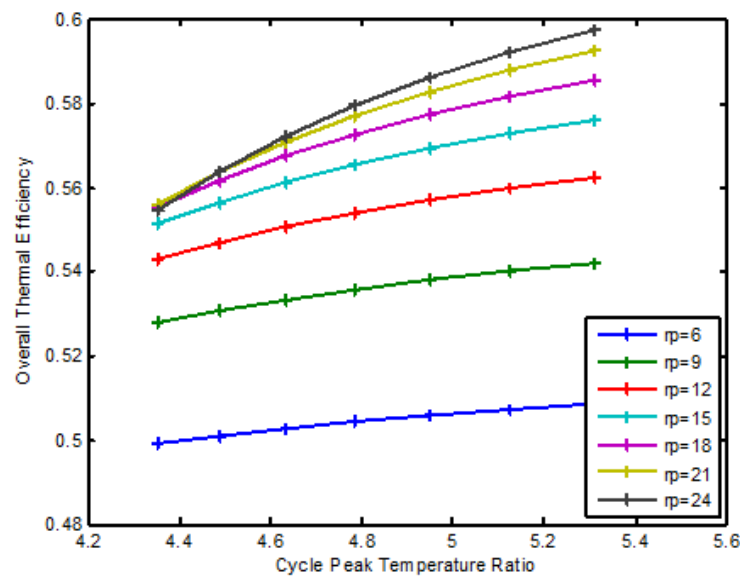

(b)

Figure 5. Variation of cycle peak temperature ratio and pressure with constant turbine inlet temperature on: a) Total power output b) Overall thermal efficiency.

Figure 6 presents the effects of the variation of cycle peak temperature ratio, isentropic compressor efficiency on total power output and overall thermal efficiency of CCPP. It was noticed that the cycle peak temperature ratio as well as increases in the isentropic compressor efficiency of the GT cycle led to the increase of the total power output of the CCPP, as shown in Figure 6(a). The overall thermal efficiency increased 
with the increase of the cycle peak temperature ratio and increased the isentropic compressor efficiency as shown in Figure 6(b). However, the variation of overall thermal efficiency was significant at the lower cycle peak temperature ratio. Figure 7 showed the comparison between simulated power outputs of the CCPP cycle and simple GT cycle versus the practical results from the Baiji gas turbine power plant. It can be seen that the power output from the combined cycle gas GT power plant was much higher compared to the single shaft GT cycle as well as the practical single GT power plant (Baiji GT Power Plant).

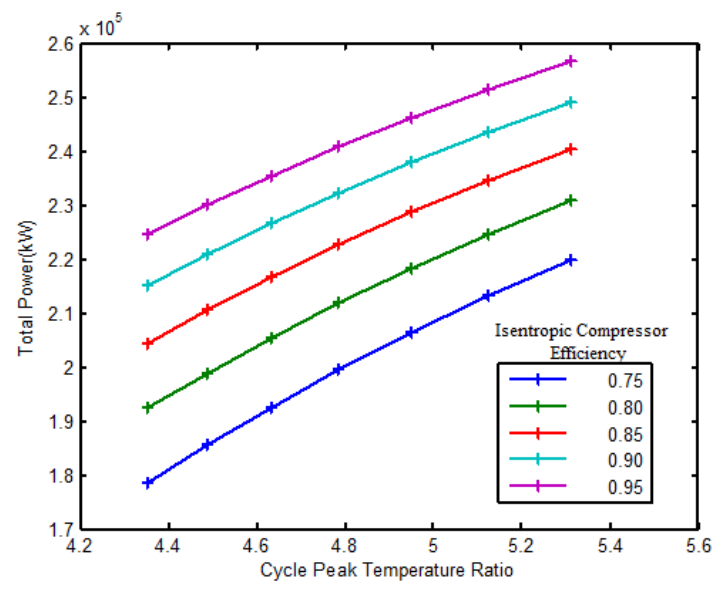

(a)

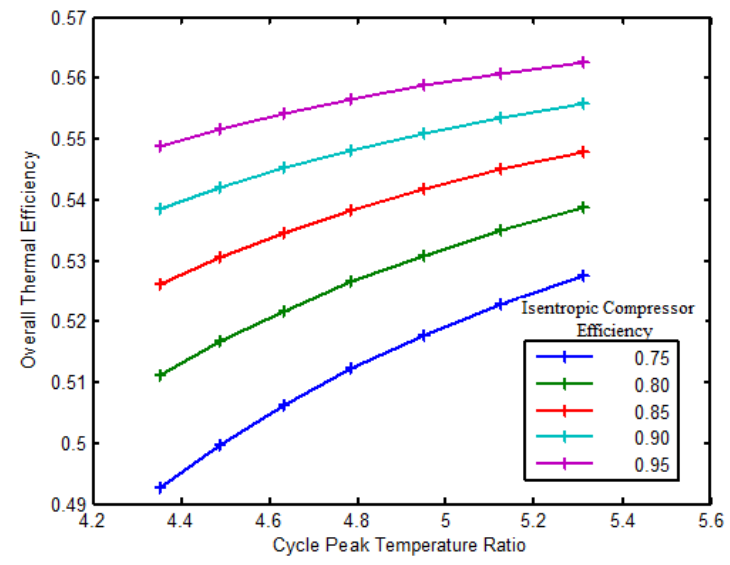

(b)

Figure 6. Variation of cycle peak temperature ratio and isentropic compressor efficiency on (a) Total power output; (b) Overall thermal efficiency.

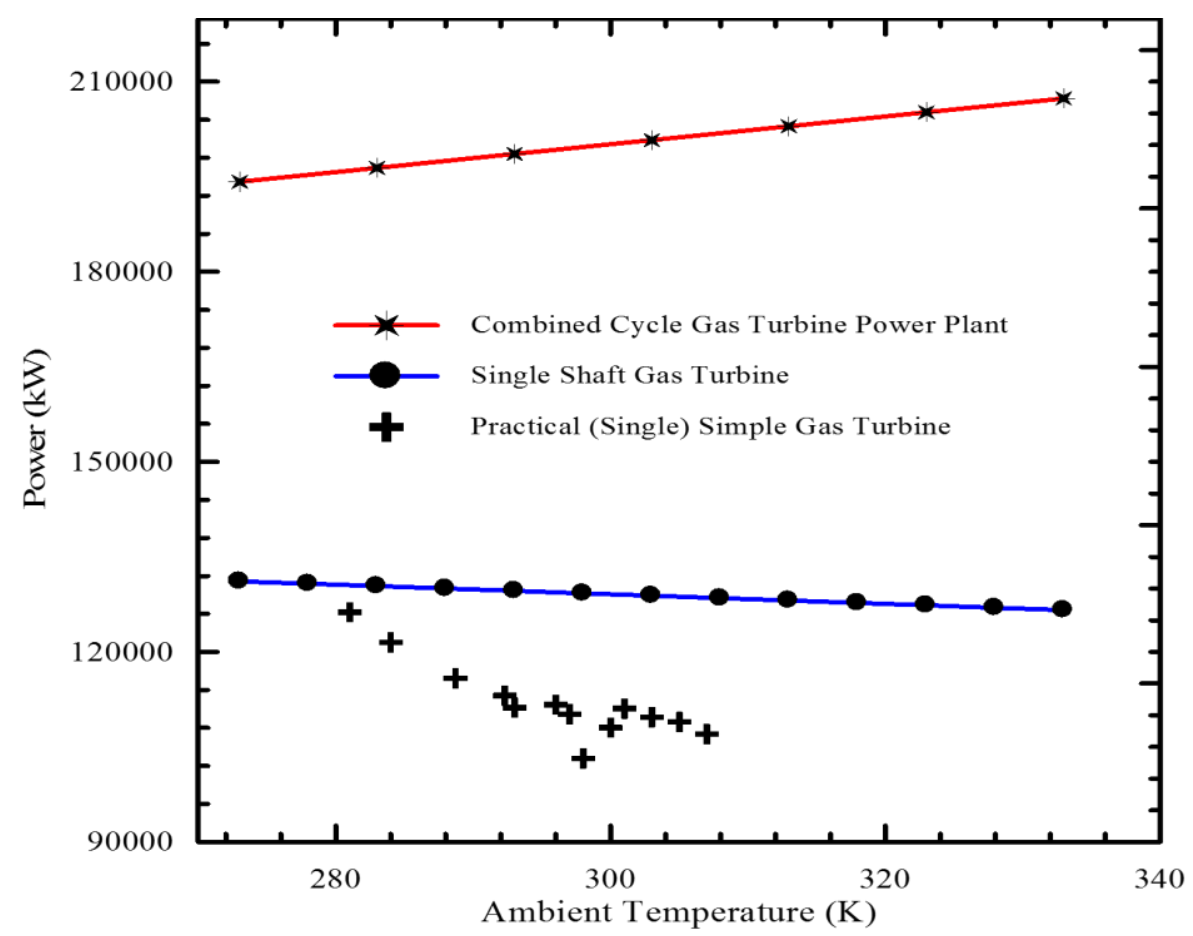

Figure 7. Comparison between simulated power outputs combined cycle and simple gas turbine versus practical results from the Baiji gas turbine power plant. 


\section{CONCLUSIONS}

The generic model of a simple GT cycle and ST cycle based on CCPP with the effects of the cycle peak temperature ratio of the GT had been used in this work based on the thermodynamics analysis. The cycle peak temperature ratios, isentropic efficiencies as well as the air-fuel ratios were strongly significant on the thermal efficiency of the CCPP. The CCPP overall thermal efficiency was greater than the GT thermal efficiency. The CCPP efficiency ranged at about 56\%. At the constant turbine inlet temperature (TIT), the total power output and the overall thermal efficiency increased with the increase of the cycle peak temperature ratio of the GT.

\section{ACKNOWLEDGMENT}

The authors would like to thank Universiti Malaysia Pahang for providing laboratory facilities and financial support under the research grant (RDU150334).

\section{REFERENCES}

[1] Basrawi F, Ibrahim TK, Habib K, Yamada T. Effect of operation strategies on the economic and environmental performance of a micro gas turbine trigeneration system in a tropical region. Energy. 2016;97:262-72.

[2] Muda N, Boosroh M. Gasification of coal-petcoke blends in a pilot scale gasification plant. International Journal of Automotive and Mechanical Engineering. 2013;8:1457.

[3] Basrawi F, Chand M, Koo K, Ibrahim TK. Theoretical analysis on the economic performance of micro gas turbine-trigeneration system with different operation strategies for residential building in a tropical region. MATEC Web of Conferences: EDP Sciences; 2016.

[4] Dincer I, Rosen MA, Zamfirescu C. Exergetic performance analysis of a gas turbine cycle integrated with solid oxide fuel cells. Journal of Energy Resources Technology. 2009;131:032001-.

[5] Ibrahim TK, Mohammed MN. Thermodynamic evaluation of the performance of a combined cycle power plant. International Journal of Energy Science and Engineering. 2015;1:11.

[6] Basrawi F, Ibrahim TK, Lee GC, Habib K, Ibrahim H. Effect of solar fraction on the economic and environmental performance of solar air-conditioning by adsorption chiller in a tropical region. Journal of Solar Energy Engineering. 2015;137:061009.

[7] Ibrahim TK. The Life cycle assessments of gas turbine using inlet air cooling system. Tikrit Journal of Engineering Science. 2015;22:69-75.

[8] Said MM, Aroussi A. Utilization of pulverised coal monitoring system for cleaner electricity generation. International Journal of Automotive and Mechanical Engineering. 2014;9:1588.

[9] Ibrahim TK, Rahman M. Effect of the isentropic efficiency and enhancing strategies on the performance of gas turbine. Journal of Mechanical Engineering and Sciences. 2013;4:383-96.

[10] Ganjehkaviri A, Mohd Jaafar MN, Hosseini SE. Optimization and the effect of steam turbine outlet quality on the output power of a combined cycle power plant. Energy Conversion and Management. 2015;89:231-43. 
[11] Rovira A, Sánchez C, Muñoz M. Analysis and optimisation of combined cycles gas turbines working with partial recuperation. Energy Conversion and Management. 2015;106:1097-108.

[12] Rahman M, Ibrahim TK, Taib M, Noor M, Kadirgama K, Bakar RA. Thermal analysis of open-cycle regenerator gas-turbine power-plant. World Academy of Science, Engineering and Technology Journal. 2010;68:6.

[13] Zhang G, Zheng J, Yang Y, Liu W. Thermodynamic performance simulation and concise formulas for triple-pressure reheat HRSG of gas-steam combined cycle under off-design condition. Energy Conversion and Management. 2016;122:37285.

[14] Ibrahim TK, Rahman M. Effects of isentropic efficiencies on the performance of combined cycle power plants. International Journal of Automotive \& Mechanical Engineering. 2015;12.

[15] Ibrahim TK, Rahman M. Parametric simulation of triple-pressure reheat combined cycle: A case study. Advanced Science Letters. 2012;13:263-8.

[16] Ibrahim TK, Rahman MM. Effects of isentropic efficiency and enhancing strategies on gas turbine performance. Journal of Mechanical Engineering and Sciences. 2013;4:383-96.

[17] Ibrahim TK, Rahman MM, Mohammed MK, Basrawi F. Statistical analysis and optimum performance of the gas turbine power plant. International Journal of Automotive and Mechanical Engineering. 2016;13:3215-.

[18] Ibrahim TK, Rahman MM. Effects of isentropic efficiencies on the performance of combined cycle power plants. International Journal of Automotive and Mechanical Engineering. 2015;12:2914-28.

[19] Benato A, Stoppato A, Bracco S. Combined cycle power plants: A comparison between two different dynamic models to evaluate transient behaviour and residual life. Energy Conversion and Management. 2014;87:1269-80.

[20] Ibrahim TK, Rahman M. Effect of compression ratio on performance of combined cycle gas turbine. International journal of energy engineering. 2012;2:9-14.

[21] Ibrahim TK, Rahman M. Effective Parameters on performance of multipressure combined cycle power plants. Advances in Mechanical Engineering. 2014;6:781503.

[22] Khaljani M, Khoshbakhti Saray R, Bahlouli K. Comprehensive analysis of energy, exergy and exergo-economic of cogeneration of heat and power in a combined gas turbine and organic Rankine cycle. Energy Conversion and Management. 2015;97:154-65.

[23] Can Gülen S. Étude on Gas Turbine Combined Cycle Power Plant-Next 20 Years. Journal of Engineering for Gas Turbines and Power. 2015;138:051701-.

[24] Ibrahim TK, Rahman MM. Effect of compression ratio on the performance of different strategies for the gas turbine. International Journal of Automotive and Mechanical Engineering. 2014;9:1747-57.

[25] Ibrahim TK, Rahman M. Optimum performance improvements of the combined cycle based on an intercooler-reheated gas turbine. Journal of Energy Resources Technology. 2015;137:061601.

[26] Ibrahim TK, Rahman M. Thermal impact of operating conditions on the performance of a combined cycle gas turbine. Journal of applied research and technology. 2012;10:567-77. 
[27] Ibrahim TK, Rahman M. Parametric study of a two-shaft gas turbine cycle model of power plant. IOP Conference Series: Materials Science and Engineering: IOP Publishing; 2012. p. 012024.

[28] Ibrahim TK, Rahman M, Alla ANA. Study on the effective parameter of gas turbine model with intercooled compression process. Scientific Research and Essays. 2010;5:3760-70.

[29] Ibrahim TK, Rahman M, Sharma K. Influence of Operation Conditions on Performance of Combined Cycle Gas Turbine. International Conference on Mechanical and Electrical Technology, 3rd,(ICMET-China 2011), Volumes 1-3: ASME Press; 2011. p. 9-15.

[30] Ganapathy V. Waste heat boiler deskbook. 1991.

[31] Ibrahim TK, Rahman M, Ali OM, Basrawi F, Mamat R. Optimum performance enhancing strategies of the gas turbine based on the effective temperatures. MATEC Web of Conferences: EDP Sciences; 2016.

[32] Ibrahim TK, Rahman MM. Study on effective parameter of the triple-pressure reheat combined cycle performance. Therm Sci. 2013;17:497-508.

[33] Rahman MM, Ibrahim TK, Kadirgama K, Mamat R, Bakar RA. Influence of operation conditions and ambient temperature on performance of gas turbine power plant. Advanced Materials Research: Trans Tech Publ; 2011. p. 3007-13.

[34] Rahman M, Ibrahim TK, Abdalla AN. Thermodynamic performance analysis of gas-turbine power-plant. International Journal of Physical Sciences. 2011;6:353950 .

[35] Ibrahim TK, Rahman M. Effect of compression ratio on the performance of different strategies for the gas turbine. International Journal of Automotive and Mechanical Engineering. 2014;9:1747.

[36] Bracco S, Siri S. Exergetic optimization of single level combined gas-steam power plants considering different objective functions. Energy. 2010;35:5365-73.

[37] Mazzi N, Rech S, Lazzaretto A. Off-design dynamic model of a real Organic Rankine Cycle system fuelled by exhaust gases from industrial processes. Energy. 2015;90, Part 1:537-51.

[38] Bassily A. Numerical cost optimization and irreversibility analysis of the triplepressure reheat steam-air cooled GT commercial combined cycle power plants. Applied Thermal Engineering. 2012;40:145-60.

[39] Vijayaraghavan S, Goswami DY. Organic Working Fluids for a Combined Power and Cooling Cycle. Journal of Energy Resources Technology. 2005;127:125-30.

[40] Woudstra N, Woudstra T, Pirone A, Stelt Tvd. Thermodynamic evaluation of combined cycle plants. Energy Conversion and Management. 2010;51:1099-110.

[41] Vučković GD, Stojiljković MM, Vukić MV. First and second level of exergy destruction splitting in advanced exergy analysis for an existing boiler. Energy Conversion and Management. 2015;104:8-16.

[42] Anastasovski A, Rašković P, Guzović Z. Design and analysis of heat recovery system in bioprocess plant. Energy Conversion and Management. 2015;104:3243.

[43] Aminov Z, Nakagoshi N, Xuan TD, Higashi O, Alikulov K. Evaluation of the energy efficiency of combined cycle gas turbine. Case study of Tashkent thermal power plant, Uzbekistan. Applied Thermal Engineering. 2016;103:501-9.

[44] Aurousseau A, Vuillerme V, Bezian J-J. Control systems for direct steam generation in linear concentrating solar power plants-A review. Renewable and Sustainable Energy Reviews. 2016;56:611-30. 
[45] Mira SS, Doty JH. Statistical Exergy-based analysis of a steam power plant for concept verification and plant optimization. ASME 2015 Power Conference collocated with the ASME 2015 9th International Conference on Energy Sustainability, the ASME 2015 13th International Conference on Fuel Cell Science, Engineering and Technology, and the ASME 2015 Nuclear Forum: American Society of Mechanical Engineers; 2015. p. V001T07A2-VT07A2.

[46] Sreekanth M, Daniel J. Implementing results of exergy analysis in steam turbine power plants. International Journal of Applied Engineering Research. 2015;10:32113-23. 